\title{
MINERAL CONTENT AND PHYTOCHEMICAL PROPERTIES OF SELECTED CAULERPA SPECIES FROM MALAYSIA
}

\author{
Mohd Fakhrulddin Ismail ${ }^{1 a^{*}}$, Shiamala Devi Ramaiya ${ }^{2 b}$, Muta Harah Zakaria ${ }^{3 c}$, Natrah Fatin \\ Mohd Ikhsan ${ }^{4 d}$ and Mohd Azrie Awang ${ }^{5 d}$
}

\begin{abstract}
${ }^{a}$ International Institute of Aquaculture and Aquatic Sciences (I-AQUAS), Universiti Putra Malaysia (UPM), 71050 Port Dickson, Negeri Sembilan, MALAYSIA. Email: m_fakhrulddin@upm.edu.my ${ }^{1}$

bUniversiti Putra Malaysia Bintulu Sarawak Campus, 97008 Bintulu, Sarawak, MALAYSIA. Email: shiamala@upm.edu.my²

${ }^{\mathrm{c}}$ Department of Aquaculture, Faculty of Agriculture, Universiti Putra Malaysia, 43400 UPM Serdang, Selangor, MALAYSIA. Email: muta@upm.edu.my ${ }^{3}$

${ }^{\mathrm{d} G a n o f a r m ~ R \& D ~ S D N ~ B H D, ~ S k y-P o d ~ S q u a r e, ~ P e r s i a r a n ~ P u c h o n g ~ J a y a ~ S e l a t a n, ~ B a n d a r ~ P u c h o n g ~ J a y a, ~} 47100$ Puchong, Selangor, MALAYSIA. Email: natrah@upm.edu.my ${ }^{4}$; azrieishar@gmail.com ${ }^{5}$
\end{abstract}

Corresponding Author: m_fakhrulddin@upm.edu.my

Received: $23^{\text {rd }}$ May $2020 \quad$ Accepted: $7^{\text {th }}$ Sep 2020

Published: $31^{\text {st }}$ Oct 2020

DOI: https://doi.org/10.22452/mjs.vol39no3.10

\begin{abstract}
Seaweeds are abundant and are an important renewable resource for the coastal community since they are rich sources of minerals and natural bioactive compounds. Among them, the Caulerpa species under green seaweeds is widely consumed by locals in Southeast Asia. Edible seaweeds are often associated with various health benefits. However, in Malaysia, limited studies have been done on the mineral and antioxidant levels of seaweeds, especially for the Caulerpa species. Thus, the present study aimed to evaluate the variations of minerals and antioxidants of selected Caulerpa species in Malaysia. The samples were collected in two study sites, which were Blue Lagoon, Port Dickson and Merambong Shoal, Johor. Two species, C. racemosa and $C$. manorensis were recorded from Merambong Shoal, Johor, while five species were recorded namely C. sertularioides, $C$. racemosa var lamourouxii, $C$. lentillifera, $C$. racemosa var cylindracea and $C$. racemosa at Blue Lagoon, Port Dickson. Among all the Caulerpa species from both study sites, $C$. manorensis possessed the highest phosphorus content $(139.54 \mathrm{mg} / 100 \mathrm{~g})$ while $C$. racemosa from both Merambong and Blue Lagoon Port Dickson's calcium $(\mathrm{Ca})$ content was significantly highest at 2318.33 - $2406.66 \mathrm{mg} / 100 \mathrm{~g}$. All the Caulerpa species possessed high sodium (Na) content ranging $9338.30-21748.30 \mathrm{mg} / 100 \mathrm{~g}$. For micronutrients, the highest zinc content was recorded in $C$. manorensis $(3.40 \mathrm{mg} / 100 \mathrm{~g})$ while the copper content was significantly highest in $C$. racemosa from Port Dickson $(1.05 \mathrm{mg} / 100 \mathrm{~g})$. The methanol extract of $C$. sertularioides possessed phytochemical attributes of high antioxidant activity (DPPH $\left.\mathrm{EC}_{50}=24.16 \mathrm{mg} / \mathrm{mL}\right)$ with a high FRAP value being recorded in C. lentillifera $(27.09 \mathrm{mg}$ TE/ $100 \mathrm{~g})$. The TPC and TFC were highest in C. lentillifera with $57.95 \mathrm{mg}$ GAE/100g and $1506.41 \mathrm{mg}$ QE/100g respectively. The present study revealed that Caulerpa species contained constituents with significant mineral compositions and phytochemical attributes suitable for pharmaceutical and nutraceutical uses.
\end{abstract}

Keywords: Seaweeds, mineral content, total flavonoid content, antioxidant, total phenolic content.

\section{INTRODUCTION}

Seaweeds are known as a group of plants under diverse algal classifications. They are mainly classified into Chlorophyta, Phaeophyta and Rhodophyta, based on their pigmentations, (green, brown and red) (Mohamed et al., 2012). Rhodophyta consists of 6000 species 
and is the most abundant compared to Chlorophyta (1200 species) and Phaeophyta (200 species) (Venugopal, 2011). As a primitive plant, seaweed does not produce flowers; instead, it relies on spores to spread. The plant produces thallus formations that are root-like, leaf-like and stem-like. Seaweeds are important marine renewable resources which are rich sources of minerals and natural bioactive compounds (Kamaladhasan and Subramanian, 2009; Selvaraj et al., 2010; Domettila et al., 2013). The marine algae in Malaysia, according to Phang et al., (2006), consist of 381 species with 105 species from Chlorophyta, 186 species from Rhodophyta, 73 species from Phaeophyta and 17 taxa from Cyanophyta.

The Caulerpa species is widely distributed in Malaysia and is often consumed as a raw salad by the locals, especially in Sabah and Sarawak (Du et al., 2009; Phang et al., 2005; Phang et al., 2008; Gan et al., 2011; Thilahgavani and Charles, 2014; Zawawi et al., 2015), especially $C$. lentillifera and $C$. racemosa, also known as "sea grape" or called locally as 'Latok' (Nagappan and Vairappan, 2014; de Gaillande et al., 2017; Yap et al., 2019).

The seaweeds under the genus Caulerpa are characterised as coenocytic, where a single cell contains many nuclei. This species is often found attached to rocks, coral rubble and sometime on sandy to muddy substrates. Due to its diverse adaptation, this species is invasive by nature (Jousson et al., 2000; Ramesh et al., 2012). Research had been conducted on various seaweed species to explore their potential for human consumption and as live feed (Zemke-White and Ohno, 1999; Dinabandu and Charles, 2005; Matanjun et al., 2008; 2009). Seaweed species are also known for being high in non-starch polysaccharides and possess ample minerals, fatty acids, antibiotics, amino acids with phytochemical properties which are useful for pharmaceutical and nutraceutical applications (Cavas and Pohnert, 2010; Matanjun et al., 2008; Mabeau and Fleurence, 1993; Yow et al., 2011).
Although, many seaweed species had been studied, limited research reports documented the minerals and antioxidant activities of Caulerpa species, especially in Malaysia. The diversity in the biochemical composition of Caulerpa provides an opportunity for further exploration of this seaweed (Holdt and Kraan, 2011). There is a need for more information to better understand the nutritional profiles of the exact species consumed and their biological potentials. An in-depth systematic assessment of selected species of Caulerpa that describes their nutritional values and the presence of phytochemical compounds is an important aspect to better understand their significance as a marine salad and functional food. The aims of this study were to evaluate the mineral contents and phytochemical attributes of selected Caulerpa species in Malaysia.

\section{METHODS}

\subsection{Sample collection}

The Caulerpa species namely, $C$. racemosa, $C$. manorensis, $C$. sertularioides, $C$. racemosa var lamourouxii, $C$. lentillifera, $C$. racemosa var cylindracea were collected from Merambong Shoal, Johor $\left(1^{\circ} 20^{\prime} 52.2^{\prime \prime} \mathrm{N}\right.$, $\left.103^{\circ} 35^{\prime} 53.6^{\prime \prime} \mathrm{E}\right)$ and Blue Lagoon, Port Dickson $\left(2^{\circ} 32^{\prime} 00.0^{\prime \prime} \mathrm{N} 101^{\circ} 55^{\prime} 00.0 " \mathrm{E}\right)$ from April to September 2018 during low tide. The samples were then transported to the laboratory for further processing. The samples were washed with running seawater to remove the debris attached and they were then dried under room temperature $\left(25-29^{\circ} \mathrm{C}\right)$ for 2 to 4 days. The dried Caulerpa species were then ground using a pestle and mortar and were kept in a sealed bag and stored inside a desiccator prior to further analysis.

\subsection{Mineral analysis}

\subsubsection{Sample preparation}

The atomic absorption spectrophotometric (AAS) method was used to determine the levels of the minerals sodium 
$(\mathrm{Na})$, magnesium $(\mathrm{Mg})$, calcium $(\mathrm{Ca})$, zinc $(\mathrm{Zn})$ copper $(\mathrm{Cu})$ and potassium $(\mathrm{K})$ (AOAC, 2000). Prior to the mineral analysis, the samples were ashed using the dry ashing method 930.05 following AOAC, (2000), to eliminate organic substances, leaving pure inorganic residues (minerals). Air dried samples were incinerated in a furnace $\left(550^{\circ} \mathrm{C}\right)$ for 5-6 hours to obtain the ash values. The ash obtained was wetted with two drops of distilled water. This was accompanied by the addition of $2 \mathrm{ml}$ of concentrated HCL and evaporated on a hot plate to dryness. The samples were then added with $10 \mathrm{ml}$ of $20 \% \mathrm{HNO}_{3}$ and evaporated until half of the solution was left. The crucible was allowed to cool before the samples were moved into a volumetric flask and the volume was rendered to $100 \mathrm{ml}$. The extract was used for mineral content analysis.

\subsubsection{Determination of macro- and micronutrients}

For the determination of macronutrients ( $\mathrm{Na}, \mathrm{K}, \mathrm{Ca}, \mathrm{Mg}$,), the sample extract was diluted by 100 factor dilution, whereas the original extract was used for micronutrient determination $(\mathrm{Cu}$ and $\mathrm{Zn})$. The standard calibration range for $\mathrm{K}, \mathrm{Ca}, \mathrm{Na}$ and $\mathrm{Cu}$ was $0,1,3,5 \mathrm{ppm}(0,0.1,0.3,0.5 \mathrm{ppm}$ for $\mathrm{Mg} ; 0,1$, 2, $3 \mathrm{ppm}$ for $\mathrm{Cu}$ ). The samples were then analysed using the PerkinElmer AnalystTM 800 Atomic Absorption Spectrophotometer (AAS).

\subsubsection{Determination of phosphorus $(P)$}

Total Phophorus (P) was identified using the UV-VIS spectrophotometer colorimetric method (UNICO, New Jersey, USA). The sample's $\mathrm{P}$ concentration was quantified by measuring the color intensity provided by the sample against the standard solutions with known phosphorus concentrations using a standard curve. The Perkin Elmer Lamda 25 UV / Vis Spectrophotometer was used to measure the sample absorbance.

\subsection{Phytochemical analyses}

\subsubsection{Sample preparation and extraction}

A total of $5 \mathrm{~g}$ of ground samples were weighed and extracted for 3 days with $250 \mathrm{ml}$ of 80 per cent methanol. The extraction was carried out with the assistance of an orbital shaker positioned at $160 \mathrm{rpm}$ to facilitate further extraction. Afterwards, the samples were centrifuged at 500 element $g$ for $10 \mathrm{~min}$. The supernatant was filtered using no. 2 Whatman filter pad A Rotary Evaporator was used to evaporate the remaining solvents.

The sample extracts were moved to a flask for distillation. The evaporation was conducted at a decreased pressure of $110 \mathrm{hPa}$ and rotated in a water bath at a speed of 4 at $35^{\circ} \mathrm{C}$. At the condenser, the residual solvent (methanol) was stored. Extracts of crude samples were stored at $4^{\circ} \mathrm{C}$ until analysis.

\subsubsection{DPPH radical scavenging activity assay}

The overall antioxidant activity (TAA) of the plant extracts from Caulerpa against DPPH radicals was determined using the methods adapted by Brand-Williams et al., (1995). A 100 microns DPPH stock solution was formulated using pure methanol. The sample extracts were diluted with 80 percent methanol to a series of known concentrations. One ml of isolated sample was added to DPPH solution of $3.0 \mathrm{mg}$. The solutions were incubated under dark conditions for $30 \mathrm{~min}$ at room temperature. Using an UV/Vis spectrophotometer, the sample absorbance was measured at $517 \mathrm{~nm}$. A lower EC50 value indicated a higher antioxidant activity. Trolox was used as a standard.

\subsubsection{Ferric reducing antioxidant power assay (FRAP)}

Ferric reduction of the antioxidant power of the extract was determined using the 
FRAP test following the modified method by Benzie and Strain, (1996). Trolox was used as a standard working reagent, and TPTZ was used as a blank reference. Using the UV/Vis Spectrophotometer, the absorbance of sample and the standard was read at $595 \mathrm{~nm}$. The standard curve was made from a Trolox concentration range of $0-100 \mu \mathrm{mol}$. The findings were presented in milligrams $(\mathrm{mg})$ trolox equivalent $(\mathrm{TE}) / 100 \mathrm{~g}$.

\subsubsection{Total phenolic content (TPC)}

The Folin - Ciocalteau spectrophotometric approach as described in Singleton and Rossi, (1965) and Ramaiya et al., (2013) was used to determine the total phenolic content in extracts of Caulerpa species. Gallic acid was used as the standard of reference. The sample absorbance was measured at $740 \mathrm{~nm}$ against the standard for gallic acid. The total phenolic content of a sample was expressed as milligrams $(\mathrm{mg})$ of gallic acid equivalent (GAE)/100 g.

\subsubsection{Total flavonoid content (TFC)Total} flavonoid content (TFC), as defined by Jia et al., (1999), was calculated using an updated colorimetric test. The following experiments were carried out under ambiguous conditions. After 15 min reaction, the absorbance was measured at $510 \mathrm{~nm}$. Quercetin was the standard used, and the data were expressed as milligram (mg) quercetin equivalents (QE)/100 g.

\subsection{Statistical analysis}

A single-factor variance analysis (ANOVA) with post hoc Duncan test $(p<0.05)$ was used to compare the average analytical values for minerals and phytochemicals. $\mathrm{EC}_{50}$ values for TAA were calculated by using linear regression analysis.

\section{RESULTS AND DISCUSSION}

Different Caulerpa species were observed to grow together at the natural habitat. The Caulerpa species were observed to inhabit the rocky shore by attaching their holdfasts onto the rocks and coral crush at the sampling locations (Figure 1).
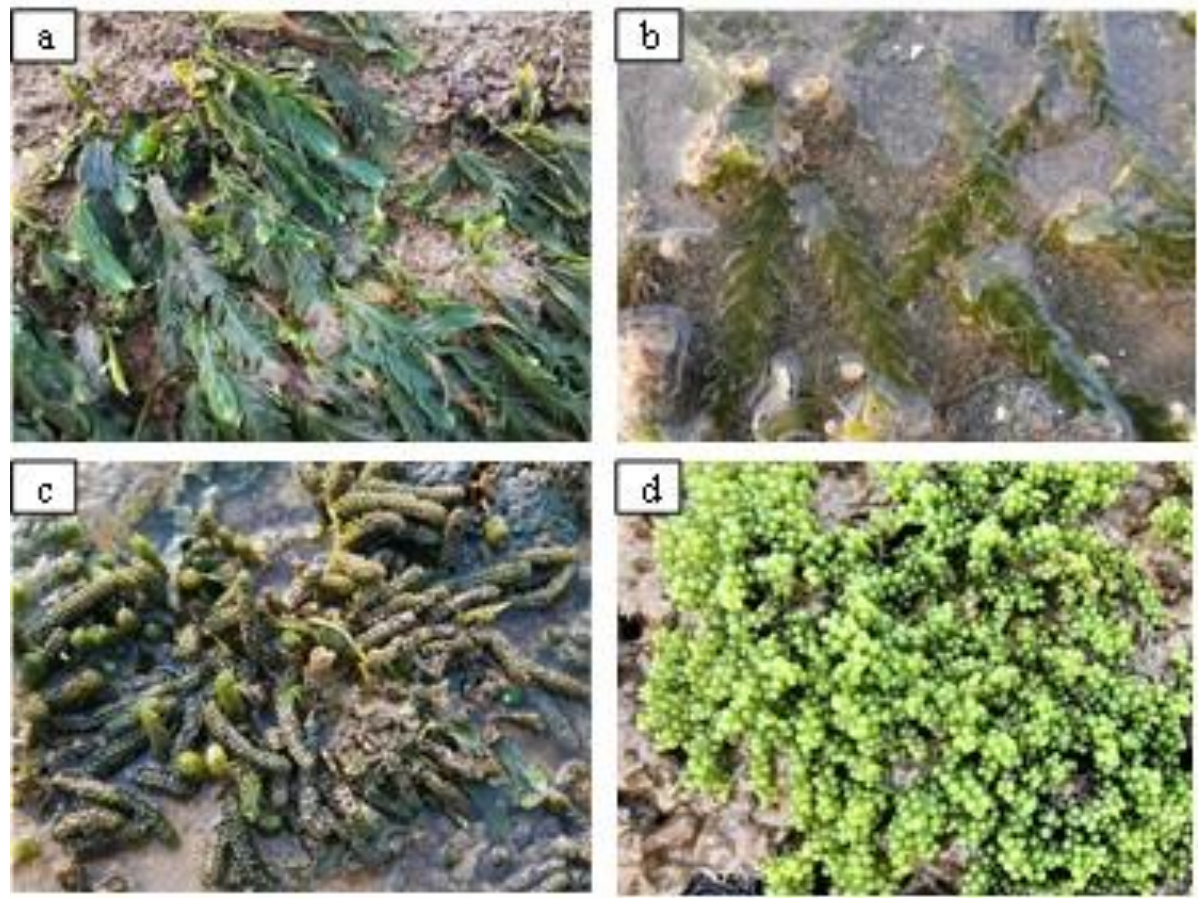

Figure 1. Caulerpa species, (a) C. sertularioides, (b) C. manorensis, (c) C. lentillifera and (d) C. racemosa at the natural habitat. 
The observations on the study area showed that at Merambong Island, Johor, two Caulerpa species were recorded i.e., $C$. racemosa and C. manorensis, which grew side by side and were associated with other seaweeds. Meanwhile, at Blue Lagoon, Port Dickson, five Caulerpa species were observed, C. sertularioides, C. lentillifera, C. racemosa, C. racemosa var Lamourouxii and $C$. racemosa var cylindracea. The Caulerpa species at both the areas showed associations with other seaweeds and could be found side by side e.g., Gracilaria sp., Solieria robusta, and Padina sp. Although they shared the same habitat, there were differences in their biochemical contents (Sarini et al., 2014).

\subsection{Mineral contents of Caulerpa species}

The mineral contents of the Caulerpa species are presented in Table 1. The results showed that the Caulerpa species had significant variations of macro- and micronutrients among different species or locations. Among the macronutrients, $C$. manorensis from Merambong possessed higher phosphorus (P) $(139.54 \pm 2057 \mathrm{mg} / 100$ g) compared to $C$. racemosa from Merambong and Port Dickson which possessed the least $\mathrm{P}$ content; $77.20 \pm 8.00$ and $75.83 \pm 7.88 \mathrm{mg} / 100 \mathrm{~g}$, respectively. Pattama and Anong, (2006) reported that $C$. lentillifera from Pattani Bay, Thailand contained higher $\mathrm{P}$ compositions $1030.00 \mathrm{mg} / 100 \mathrm{~g}$ compared to the present studied species of $C$. lentillifera from Port Dickson $(112.29 \pm 14.79 \mathrm{mg} / 100 \mathrm{~g})$.

The sodium $(\mathrm{Na})$ value is expected to be high in seaweeds as they grow in a saline environment compared to the value reported for terrestrial plants (USDA, 2001). Ruperez (2002) reported the $\mathrm{Na}$ contents for five species of seaweeds ranged between $3818 \pm 48$ to $7064 \pm 166 \mathrm{mg} / 100 \mathrm{~g}$. Na content was higher in $C$. racemosa from Merambong Shoal with 21748.30 $\pm 1259.66 \mathrm{mg} / 100 \mathrm{~g}$, while $C$. lentillifera from Port Dickson showed lower
$\mathrm{Na}$ content of $9338.30 \pm 183.87 \mathrm{mg} / 100 \mathrm{~g}$. Excess salt residue might interfere with the higher $\mathrm{Na}$ result caused by the air dry method. Although sodium is necessary in a healthy daily diet, its high intake has been correlated to the prevalence of hypertension (Ruperez, 2002). Calcium (Ca) in the Caulerpa species varied between species and locations. Caulerpa racemosa from Merambong and Port Dickson showed higher $\mathrm{Ca}$ content; $2318.33 \pm 94.51 \mathrm{mg} / 100 \mathrm{~g}$ and $2406.66 \pm 17.55$ $\mathrm{mg} / 100 \mathrm{~g}$, respectively. Rasyid, (2017) reported that the $\mathrm{Ca}$ in Ulva lactuca was 1828 $\mathrm{mg} / 100 \mathrm{~g}$, while $C$. lentillifera was reported by Pattama and Anong, (2006) to contain 780 $\mathrm{mg} / 100 \mathrm{~g}$ which was much lower than the studied species of $C$. lentillifera from Port Dickson $(1186.66 \pm 32.53 \mathrm{mg} / 100 \mathrm{~g})$.

For micronutrients, Zinc (Zn) was higher in $C$. manorensis from Merambong with $3.40 \pm 1.13 \mathrm{mg} / 100 \mathrm{~g}$ and was lower in $C$. sertularioides from Port Dickson with $(1.05 \pm 0.86 \mathrm{mg} / 100 \mathrm{~g})$. The $\mathrm{Zn}$ values of $C$. lentillifera from Port Dickson was 1.45 $\mathrm{mg} / 100 \mathrm{~g}$ and this was two times lower than the value reported by Pattama and Anong, (2006) of $2.6 \mathrm{mg} / 100 \mathrm{~g}$. For copper $(\mathrm{Cu})$ composition, C. racemosa from Port Dickson showed a higher value with $24.10 \pm 0.13$ $\mathrm{mg} / 100 \mathrm{~g}$, while $C$. manorensis showed the least $\mathrm{Cu}$ content with $12.56 \pm 0.96 \mathrm{mg} / 100 \mathrm{~g}$. Generally, the $\mathrm{Cu}$ contents of brown and red seaweeds were higher compared to green seaweeds. Ruperez, (2002) reported that three brown seaweeds and two red seaweeds contained less than $0.5 \mathrm{mg} / 100 \mathrm{~g}$. Zinc and copper are considered as heavy metals. All the Caulerpa species mentioned above showed the accepted levels of $\mathrm{Zn}$ and $\mathrm{Cu}$ for human consumption in Japan and France; 15.0 and $10.0 \mathrm{mg} / 100 \mathrm{~g}$, respectively (Indegaard and Minsaas, 1991; Ruperez, 2002). The variations among species and locations were difficult to explain as the mineral contents of seaweeds were reported to be varied according to species, in-situ water quality, location of 
habitat, wave activity, seasonal, environmental and physiological factors, sample handling, and method of mineralization (Ruperez, 2002; López et al., 2013; Norra et al., 2017).

\subsection{Recommended daily allowance (RDA)}

The recommended daily allowances (RDA) for human males and females (19 to 30year-olds) are presented in Table 2 for macronutrients and Table 3 for micronutrients. A plate of serving or equivalent of $10 \mathrm{~g}$ dry weight of Caulerpa species provided a macronutrient range of phosphorus between 7.58 - $13.95 \mathrm{mg} / 10 \mathrm{~g}, 1.08$ - 1.99 (\%), less than $28.70 \%$ of the RDA for both genders. Phosphorus intake is vital to the fundamental process of body metabolism and helps in bone and teeth development (Wardlaw, 2003).

Potassium ranged between 66.16 $141.00 \mathrm{mg} / 10 \mathrm{~g}, 1.40-3.00(\%)$ less than $10.00 \%$ of the RDA for both genders. Together with $\mathrm{Na}, \mathrm{K}$ also is an essential element for body regulation and electrolyte balance in the human body (Krishnaiah et al., 2008). Calcium ranged between $114.00-240.66 \mathrm{mg} / 10 \mathrm{~g}$, $11.40-24.06(\%)$ higher than $3.40 \%$ of the RDA for both genders. Ca is essential in bone formation and strength and is involved as a cofactor in enzyme systems (Martin, 1997; Wardlaw, 2003). Magnesium ranged between $62.83-93.00 \mathrm{mg} / 10 \mathrm{~g}, 14.96-22.14(\%)$, less than $24.60 \%$ of the RDA for male and 19.63 $29.06(\%)$ less than $32.30 \%$ of the RDA for female. Together with $\mathrm{Ca}, \mathrm{Mg}$ is important for neurochemical transmission and muscle excitability (Wardlaw 2003; Ramaiya et al., 2019) (Table 2).

The micronutrient content for $10 \mathrm{~g}$ dry weight of Caulerpa species showed sodium ranged between $674.67-2174.83 \mathrm{mg} / 10 \mathrm{~g}$, which was $62.25-144.98(\%)$ higher than 0.51 $\%$ of the RDA for both genders. Sodium intake is important for the maintenance of plasma and extracellular fluid. Excess sodium in the diet leads to several conditions such as heart attack, failure, disease and stroke (Lloyd-Jones et al., 2010; Benjamin et al., 2019). Copper ranged between $1.14-2.41 \mathrm{mg} / 10 \mathrm{~g}, 126.66-256.22$ (\%) higher than $103.60 \%$ of the RDA for both genders. Some seaweeds were reported to have high abilities to absorb heavy metals (Besada et al., 2019).

Zinc ranged between $0.10-0.34 \mathrm{mg} /$ $10 \mathrm{~g}, 0.95-3.09(\%)$ less than $11.60 \%$ of the RDA for male and $1.31-4.25 \%$ less than $16.00 \%$ of the RDA for female. $\mathrm{Zn}$ is essential for growth and development as it is needed in gene expression, DNA synthesis, RNA synthesis and cell division (Salgueiro et al., 2002) (Table 3). Although from the same species, the nutrient contents might be different due to geographical locations and environmental effects (Wardlaw, 2003). 
Table 1. Macro and micro mineral contents in Caulerpa species.

\begin{tabular}{|c|c|c|c|c|c|c|c|}
\hline Caulerpa species & $\begin{array}{c}\text { Phosphorus } \\
\text { (P) }\end{array}$ & Sodium (Na) & $\begin{array}{l}\text { Magnesium } \\
\text { (Mg) }\end{array}$ & Potassium (K) & Calcium (Ca) & Zink (Zn) & Copper $(\mathbf{C u})$ \\
\hline $\begin{array}{l}\text { C. sertularioides } \\
\text { Port Dickson }\end{array}$ & $123.33 \pm 14.34^{\mathrm{ab}}$ & $13043.30 \pm 47.52^{\mathrm{d}}$ & $901.66 \pm 35.47^{\mathrm{a}}$ & $1046.66 \pm 55.07^{b}$ & $1140.00 \pm 30.41^{\mathrm{e}}$ & $1.05 \pm 0.86^{\mathrm{d}}$ & $11.40 \pm 0.30^{\mathrm{f}}$ \\
\hline $\begin{array}{l}\text { C. racemosa var } \\
\text { lamourouxii, } \\
\text { Port Dickson }\end{array}$ & $115.66 \pm 7.94^{\mathrm{ab}}$ & $20550.00 \pm 562.91^{\mathrm{b}}$ & $915.00 \pm 35.00^{\mathrm{a}}$ & $1365.00 \pm 74.66^{\mathrm{a}}$ & $1538.33 \pm 27.53^{c}$ & $2.05 \pm 1.64^{\mathrm{b}}$ & $15.05 \pm 0.35^{\mathrm{d}}$ \\
\hline $\begin{array}{l}\text { C. racemosa, } \\
\text { Merambong }\end{array}$ & $77.20 \pm 8.00^{\mathrm{d}}$ & $21748.30 \pm 1259.66^{a}$ & $690.00 \pm 27.83^{c}$ & $1168.33 \pm 106.10^{b}$ & $2318.33 \pm 94.51^{\mathrm{a}}$ & $1.60 \pm 1.33^{\mathrm{bcd}}$ & $23.06 \pm 0.93^{b}$ \\
\hline $\begin{array}{l}\text { C. racemosa var } \\
\text { cylindracea Port } \\
\text { Dickson }\end{array}$ & $90.45 \pm 12.24^{\mathrm{cd}}$ & $17423.30 \pm 80.20^{c}$ & $930.00 \pm 30.00^{\mathrm{a}}$ & $1410.00 \pm 72.11^{\mathrm{a}}$ & $1718.33 \pm 94.38^{\mathrm{b}}$ & $1.20 \pm 1.12^{\mathrm{cd}}$ & $16.45 \pm 0.52^{\mathrm{c}}$ \\
\hline $\begin{array}{l}\text { C. manorensis, } \\
\text { Merambong }\end{array}$ & $139.54 \pm 2057^{\mathrm{a}}$ & $16746.70 \pm 27.53^{c}$ & $628.33 \pm 17.55^{\mathrm{c}}$ & $861.66 \pm 36.17^{\mathrm{c}}$ & $1266.66 \pm 95.04^{\mathrm{d}}$ & $3.40 \pm 1.13^{\mathrm{a}}$ & $12.56 \pm 0.96^{\mathrm{e}}$ \\
\hline
\end{tabular}




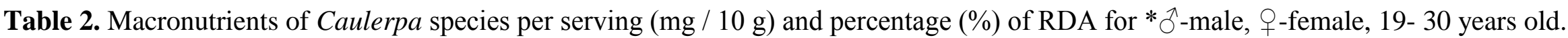

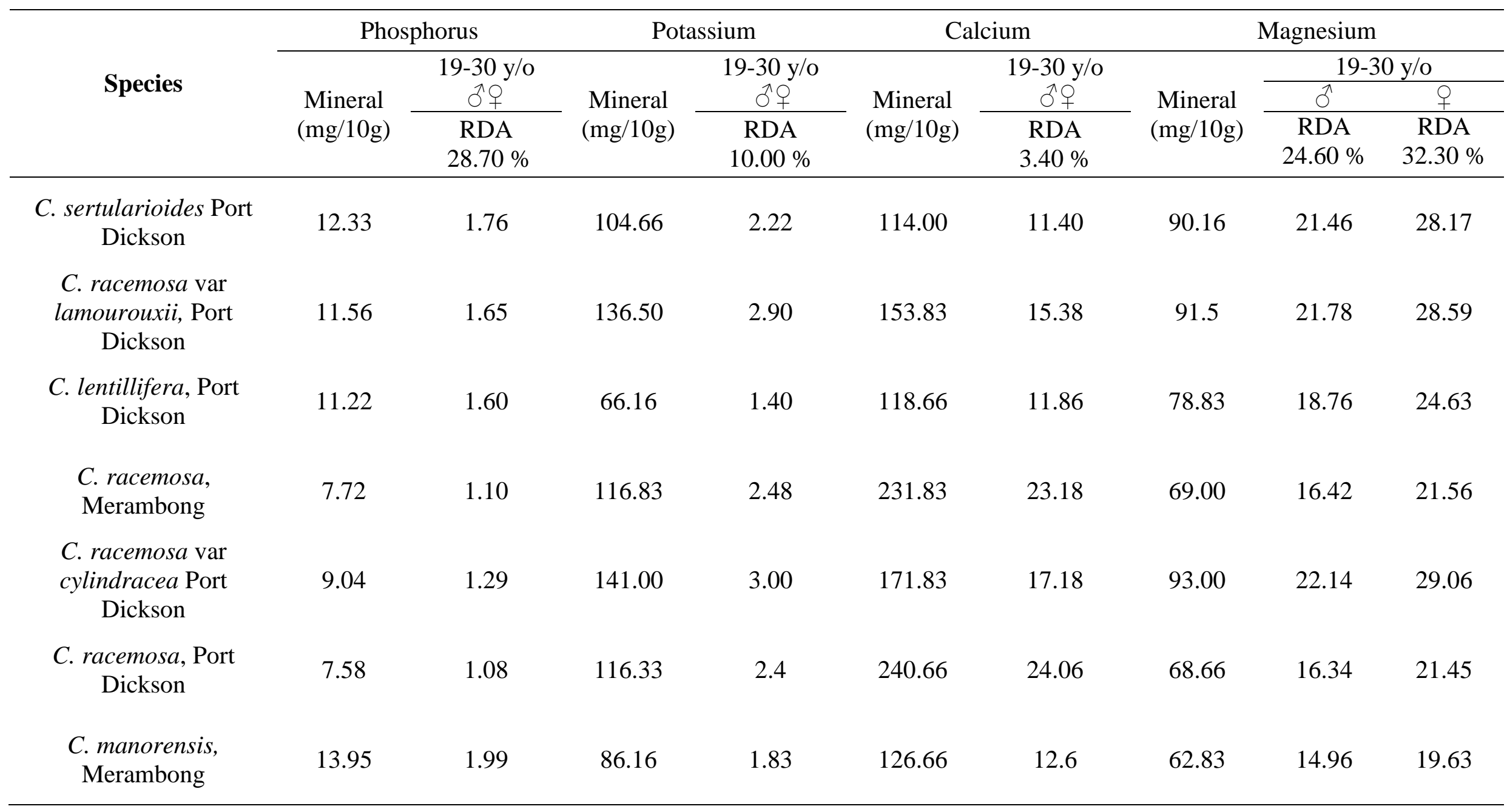




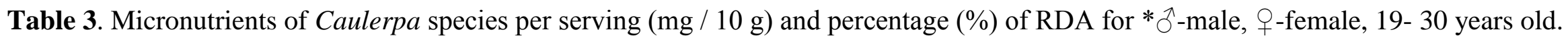

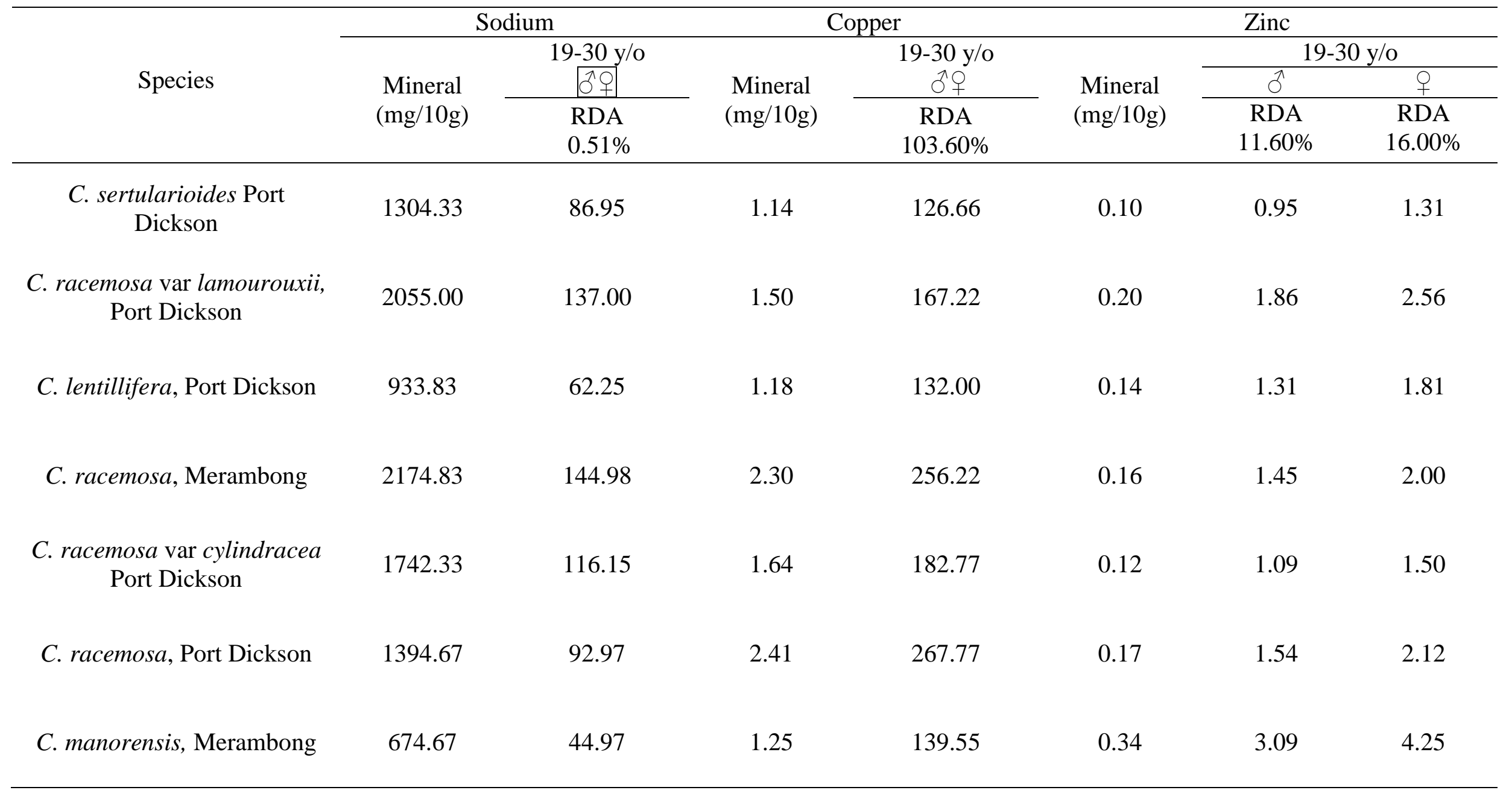




\subsection{Antioxidant activity of Caulerpa species}

\subsubsection{DPPH radical scavenging activity}

Figure 2 shows the graph of DPPH scavenging activities of selected Caulerpa species based on the result of half-maximal effective concentration $\left(\mathrm{EC}_{50}\right)$. The lower the value of $\mathrm{EC}_{50}$, the higher the antioxidant activity. The results showed that $C$. sertularioides possessed the highest antioxidant activity $(24.16 \mathrm{mg} / \mathrm{mL})$, while the lowest was recorded in $C$. racemosa var cylindracea with $62.88 \mathrm{mg} / \mathrm{mL}$. However, other species showed moderate results of antioxidant activities. The antioxidant activities of $C$. lentillifera and $C$. racemosa species were $27.77 \mathrm{mg} / \mathrm{mL}$ and $32.91 \mathrm{mg} / \mathrm{mL}$, comparatively lower than those of previous studies where $C$. lentillifera was $9.74 \mathrm{mg} / \mathrm{mL}$ and $C$. racemosa from Port Dickson was 2.51 $\mathrm{mg} / \mathrm{ml}$ (Yap et al., 2019). The results from this present analysis indicated that the variability could be due to the disparity in habitat and process of preparing samples. The degree of antioxidants present in plants is strongly affected by genetics, climate, phases of growth, cultivation method, and the analysis tool used (Zhou and Yu, 2004).

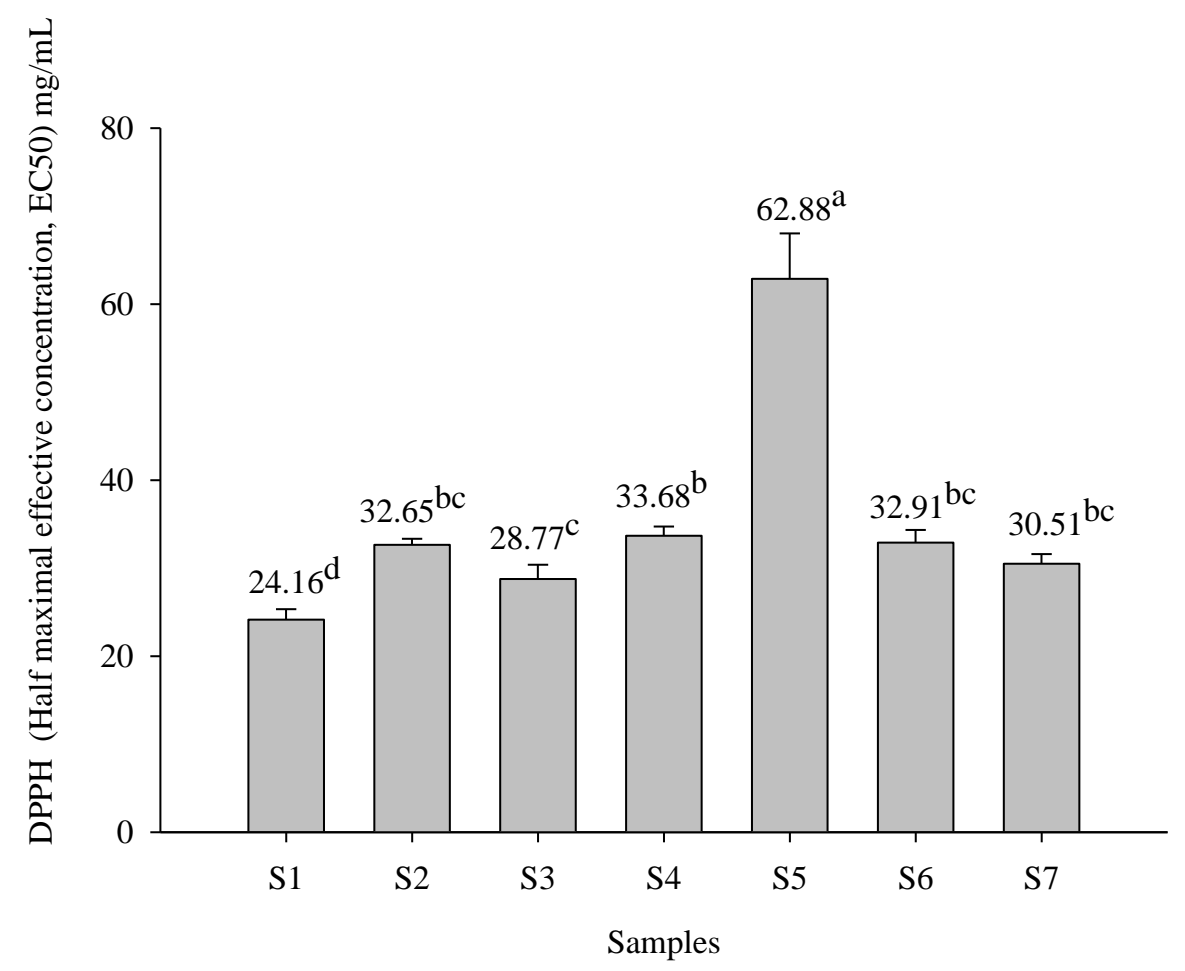

Figure 2. DPPH Radical Scavenging activities of Caulerpa sp.; C. sertularioides (S1), C. racemosa var lamourouxii (S2), C. lentillifera (S3), C. racemosa, Merambong (S4), C. racemosa var cylindracea (S5), C. racemosa, Port Dickson (S6) and C. manorensis (S7). Mean \pm SD with the same alphabet is not significantly different (DNMRT, $\mathrm{p}>0.05)$.

\subsubsection{Ferric reducing antioxidant power (FRAP)}

The FRAP was used to detect the reducing power related to the degree of hydroxylation and the extent of polyphenol conjugation (Ou et al., 2002). FRAP is an important indicator to evaluate the antioxidant potential of seaweed extracts (Vinayak et al., 2001). The reducing power of Caulerpa 
species is expressed as $\mathrm{mg} \mathrm{TE} / 100 \mathrm{~g}$ extract in Figure 3. C. lentillifera showed higher FRAP value (27.09 mg TE/100 g), while C. racemosa var cylindracea showed lower FRAP value (11.18 mg TE/100 g). The brown seaweed, Himanthalia elongate, showed a reducing power range of between $470-1170 \mathrm{mg}$
TE/100 g (Rajauria et al., 2012). Brown seaweeds are known for their high FRAP values (Matajun et al., 2008; Mole and Sabale, 2013). Meanwhile, Dovi et al., (2012) reported that green seaweeds are the second highest after brown seaweeds and red seaweeds possess the lowest FRAP values.

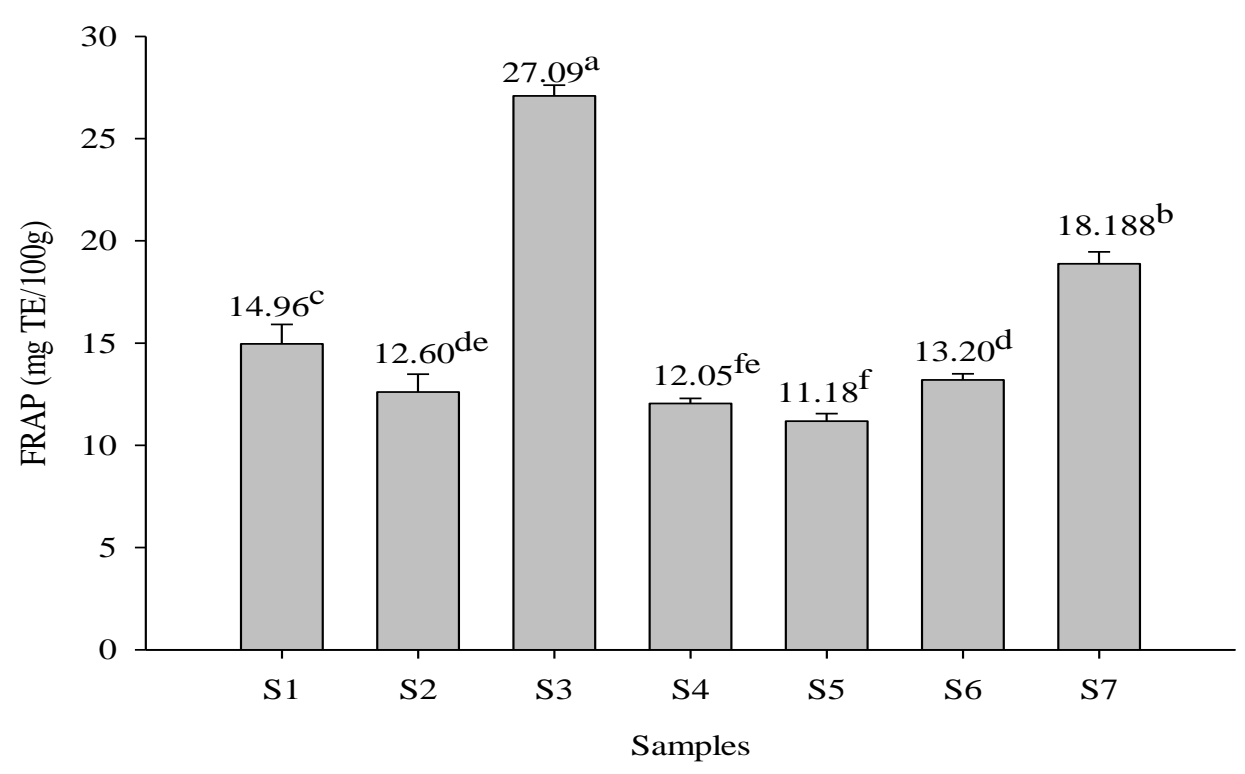

Figure 3. Ferric reducing ability of plasma (FRAP) assay of Caulerpa sp.; C. sertularioides (S1), C. racemosa var lamourouxii (S2), C. lentillifera (S3), C. racemosa, Merambong (S4), C. racemosa var cylindracea (S5), C. racemosa, Port Dickson (S6) and C. manorensis (S7). Mean \pm SD with the same alphabet is not significantly different (DNMRT, $\mathrm{p}>0.05)$.

\subsubsection{Total phenolic content (TPC) of Caulerpa species}

The TPC results of Caulerpa species are shown in Figure 4. Caulerpa lentillifera showed higher TPC value compared to the TPC values of $C$. racemosa from Merambong at $57.95 \mathrm{mg}$ GAE/100g TPC and at $15.76 \mathrm{mg}$ GAE/100g (Figure 4). Chia et al. (2015) reported that $C$. racemosa from Port Dickson contained a TPC value of $19.80 \mathrm{mg} \mathrm{GAE} / 100 \mathrm{~g}$ which was slightly lower compared to $C$. racemosa from the present study at $27.43 \mathrm{mg}$ GAE/100g. Chia et al., (2015) also reported that brown seaweeds such as $P$. tetrastromatica and $T$. ornate had higher TPC of 69.5 and $71.3 \mathrm{mg}$ $\mathrm{GAE} / 100 \mathrm{~g}$ compared to the green algae. Different studies reported that phenolic compounds have high propensities for antioxidant, anti tumor, anti-inflammatory and antiviral actions that can impact human health (Novoa et al., 2001; Thomas and Kim, 2011; Ahmad et al., 2012 Wijesingher and Jeon, 2012). The high TPC in seaweeds might be contributed by the presence of multiple phenolic groups to overcome rising oxidant levels resulting from environmental stress (Airanthi et al., 2010), temperature (Ramah et al., 2013) and salinity (Berns, 2003). 


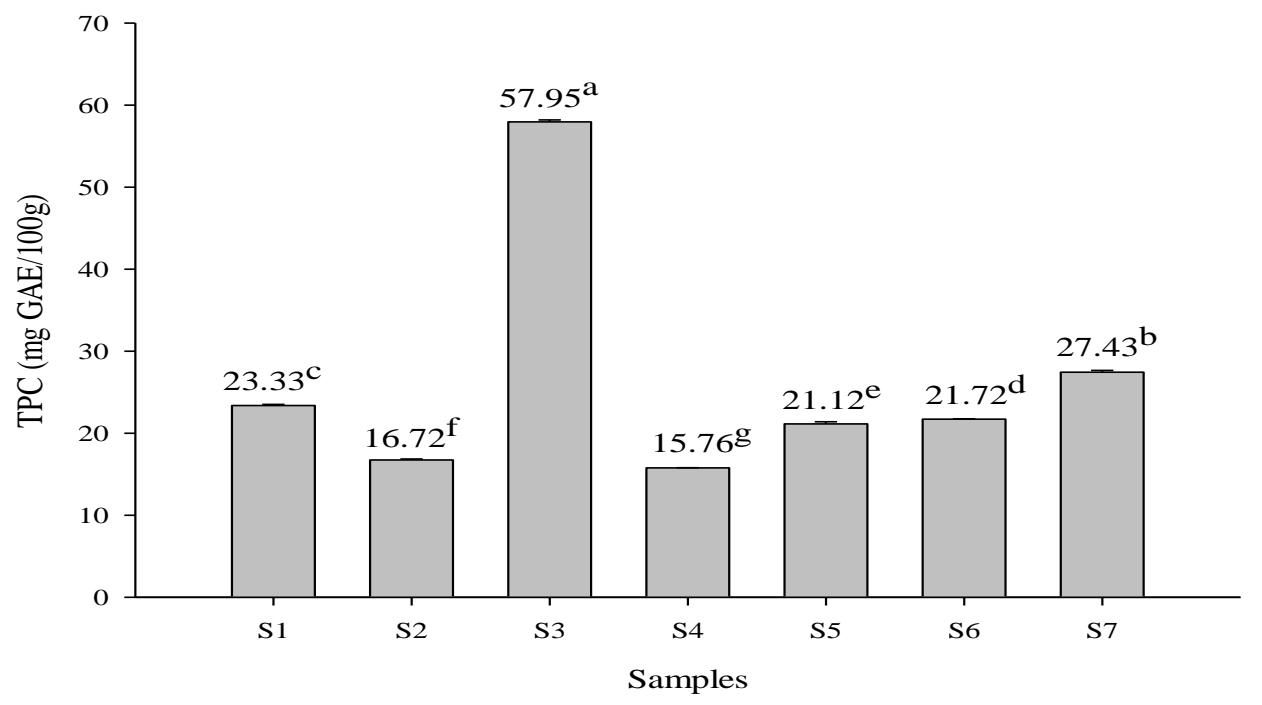

Figure 4. Total phenolic content (TPC) of methanolic extract of Caulerpa sp.; C. sertularioides (S1), C. racemosa var lamourouxii (S2), C. lentillifera (S3), C. racemosa, Merambong (S4), C. racemosa var cylindracea (S5), C. racemosa, Port Dickson (S6) and C. manorensis (S7). Mean \pm

$\mathrm{SD}$ with the same alphabet is not significantly different (DNMRT, $\mathrm{p}>0.05$ ).

\subsubsection{Total flavonoid content (TFC) of Caulerpa species}

The $\quad$ TFC values for selected Caulerpa species from Merambong and Port Dickson are presented in Figure 5. Caulerpa lentillifera from Port Dickson had the significantly highest TFC value of 1506.41 mg QE/100 g compared to the other samples, while $C$. racemosa var cylindracea from Port Dickson showed the lowest TFC value of $305.57 \mathrm{mg}$ QE/100 g. Yap et al., (2019) reported that $C$. lentillifera from Port Dickson contained a TFC value of $493.00 \mathrm{mg}$ QE/100 g, while Chia et al., (2015) reported that $C$. lentillifera from Port Dickson showed a TFC value of $1600.00 \mathrm{mg} Q \mathrm{QE} / 100 \mathrm{~g}$ when using the ethyl acetic method extraction.

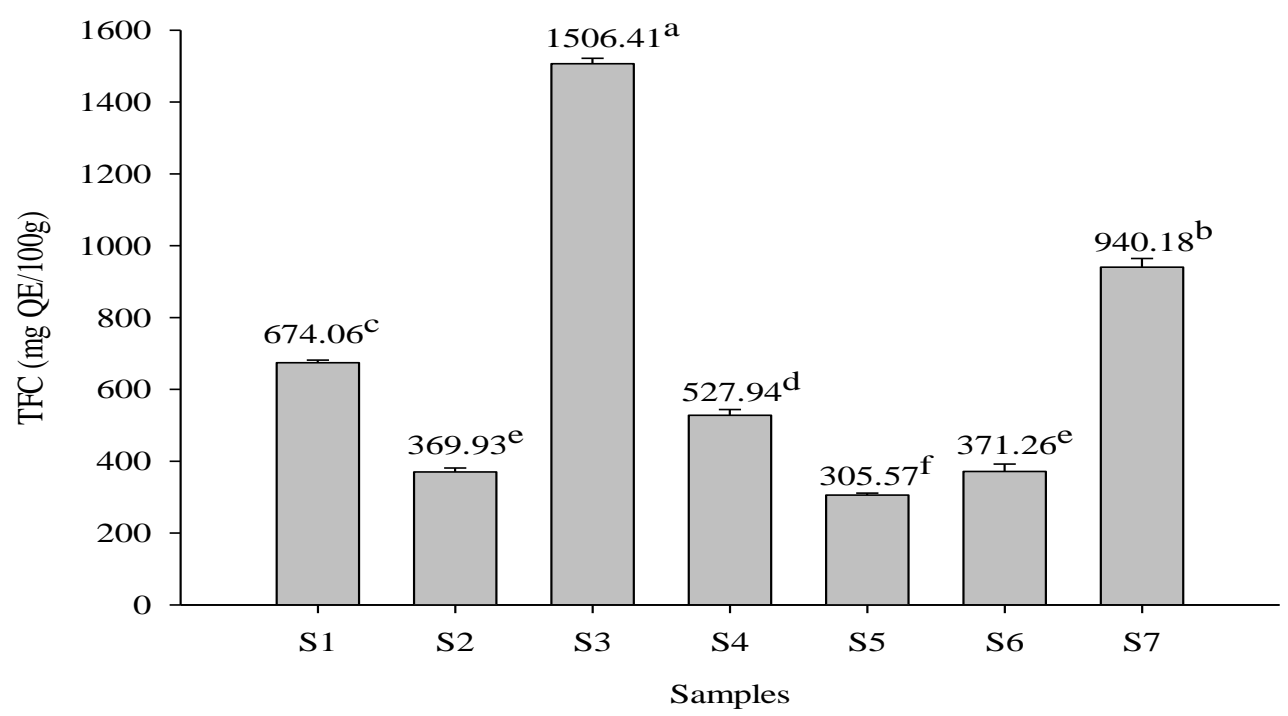

Figure 5. Total flavonoid content (TFC) of methanolic extract of Caulerpa sp.; $C$. sertularioides (S1), C. racemosa var lamourouxii (S2), C. lentillifera (S3), C. racemosa, Merambong (S4), C. racemosa var cylindracea (S5), $C$. racemosa, port Dickson (S6) and C. manorensis (S7). Mean \pm $\mathrm{SD}$ with the same alphabet is not significantly different (DNMRT, $\mathrm{p}>0.05$ ). 


\section{CONCLUSIONS}

The present findings showed that Caulerpa lentillifera and Caulerpa racemosa possessed ample minerals and phytochemicals which could provide specific health benefits for human on consumption. Besides that, the presence of good minerals and antoixidant properties in other Caulerpa species also further added value to their potential in the pharmaceutical and nurtraceutical industries. It is suggested that a detailed exploration of the bioactive compounds, palatability, and antinutritional properties of Caulerpa species is important to fully understand the worth of this seaweed.

\section{ACKNOWLEDGEMENT}

This study was funded by Universiti Putra Malaysia (UPM) under Grant IPM entitled $C$. lentillifera Morphology Under Selected Laboratory Culture "VOT: 9655400".

\section{REFERENCES}

Ahmad F., Rosni MS., Saimon W., Fook CY. \& Matajun, P. (2012). Proximate compositions and total phenolic contents of selected edible seaweed from Semporna, Sabah, Malaysia. Borneo Science 31: 85-96.

Airanthi MKWA., Hosokawa M. \& Miyashita, K. (2011). Comparative antioxidant activity of edible Japanese brown seaweeds. Journal of Food Sciences 76: 104-11.

AOAC (2000) Official Methods of Analysis. $17^{\text {th }}$ Edition, The Association of Official Analytical Chemists, Gaithersburg, MD, USA.
Benjamin EJ., Muntner P., Alonso A., Bittencourt MS., Callaway CW. \& Carson, A.P. (2019). Heart disease and stroke statistics-2019. Update: A Report from the American Heart Association. Circulation 2019 139: 56-528.

Benzie IF. \& Strain, JJ. (1996). The ferric reducing ability of plasma (FRAP) as a measure of 'antioxidant power": The FRAP assay. Analytical Biochemistry, 239: 70-76.

Berns DM. (2003). Physiological responses f Thallassia testudinum and Ruppia maritima to experimental salinity levels. Thesis (Phd), University of South Florida

Besada V., Andrade JM., Schultze F. \& Gonzalez, JJ. (2009). Heavy metal in edible seaweed commercialized for human consumption. Journal of Marine Systems 75: 305-313.

Brand-Williams W., Cuvelier ME. \& Berset, C. (1995). Use of a free radical method to evaluate antioxidant activity. LWTFood Science and Technology 28(1): 2530.

Cavas L. \& Pohnert, G. (2010). The potential of Caulerpa spp. for biotechnological and pharmacological application. In: Israel A, Einav R, Seckbach J (eds.) Seaweed and their role in globally changing environments (Cellular origin, life in extreme habitats and astrobiology), Springer, Netherlands

Chia YY., Kanthimathi MS., Khoo KS., Rajarajeswaran J., Cheng HM. \& Yap, WS. (2015). Antioxidant and cytotoxic activities of three species of tropical seaweeds. BMC Complementary and Alternative Medicine 15: 339. 
de Gaillande C., Payri C., Remoissenet G. \& Zubia, M. (2017) Caulerpa consumption, nutritional value and farming in the Indo-Pacific region. Journal of Applied Phycology 29: 22492266.

Dinabandhu S. \& Charles, Y. (2005) Mariculture of seaweeds. Academic Press.

Domettila C., Brintha TSS., Sukumaran S. \& Jeeva, S. (2013). Diversity and distribution of seaweeds in the Muttom coastal waters, south-west coast of India Biodiversity 4 (1): 105-110.

Dovi K., Ellen KP., Karla JM., Nicole KT., Patrick RW. \& Anthony, DW. (2012). Antioxidant Activity of Hawaiian Marine Algae, Marine Drugs 10(2): 403-416.

Du HL., Ooi JLS., Rosmadi F. \& Phang, SM. (2009). Spatial patterns of seaweed distribution in Malaysia using GIS. Proceedings of the SPIE, 7145, 71452H.1-71452H.9.

Gan MH., Siti Aisyah A., Nur Wahidah A., Amyra Suryatie K. \& Noraien, MP. (2011) The diversity of seaweed in the veracity of Johor: with emphasis on the east coast Peninsular Malaysia expedition II 2006. Proceedings of Universiti Malaysia Terengganu International Annual Symposium, Terengganu, Malaysia, July 11-13, 2011, 429-433

Holdt SL. \& Kraan, S. (2011). Bioactive compounds in seaweed: functional food applications and segislation. Journal of Applied Phycology 23(3): 543-597.

Indegaard M. \& Minsaas, J. (1991). Animal and human nutrition. In: Guiry MD, Blunden G (eds.), Seaweed resources in
Europe uses and potential, John Wiley and Sons Ltd.

Jia ZS., Tang MC. \& Wu, JM. (1999). The determination of flavonoid contents in mulberry and their scavenging effects on superoxide radicals. Food Chemistry 64(4): 555-559.

Jousson O., Pawlowski J., Zaninetti I., \& Zechman, FW. (2000). Invasive alga reaches California. Nature 408: 157-158.

Kamaladhasan N. \& Subramanian, SK. (2009). Influence of seaweed liquid fertilizers on legume crop, red gram. Journal of Basic Applied Biology 3(1-2): 21-24.

Krishnaiah D., Sarbatly R., Prasad DMR. \& Bono, A. (2008). Mineral content of some seaweeds from Sabah's South China Sea. Asian Journal of Scientific Research 1(2): 166-170.

Lloyd-Jones DM., Hong Y., Labarthe D., Mozaffarian D., Appel LJ., Van Horn L., Greenlund K., Daniels S., Nichol G., Tomaselli GF., Arnett DK., Fonarow GC., Ho PM., Lauer MS., Masoudi FA., Robertson RM., Roger V., Schwamm LH., Sorlie P., Yancy CW. \& Rosamond, WD. (2010). Defining and setting national goals for cardiovascular health promotion and disease reduction: the American Heart Association's Strategic Impact Goal through 2020 and beyond. Circulation. 121: 586-613.

López J., Vega-Gálvez A., Torres MJ., LemusMondaca R., Quispe-Fuentes I. \& Scala, KD. (2013). Effect of dehydration temperature on physicochemical properties and antioxidant capacity of goldenberry (Physalis peruviana L.) Chilean Journal of Agricultural Research 73(3): 293-300. 
Mabeau S. \& Fleurence, J. (1993). Seaweed in food products: biochemical and nutritional aspects. Trends in Food Science and Technology 4: 103-107.

Martin E. (1997). Principles of Human Nutrition. London: Chapman and Hall.

Matanjun P., Mohamed S., Mustapha NM. \& Muhammad, K. (2009). Nutrient Content of tropical edible seaweeds, eucheuma cottonii, Caulerpa lentillifera and Sargassum polycystum. Journal of Applied Phycology 21: 75-80.

Matanjun P., Mohamed S., Mustapha NM., Muhammad K. \& Ming, CH. (2008). Antioxidant activities and phenolics content of eight species of seaweeds from north Borneo. Journal of Applied Phycology 20: 367-373.

Mohamed S., Hashim SN. \& Rahman, HA. (2012). Seaweeds: A sustainable functional food for complementary and alternative therapy. Trends in Food Science and Technology 23(2): 83-96.

Mole MN. \& Sabale, BA. (2013). Antioxidant potential of seaweed from Kunakeswar along the west coast Mahashtra. Asian Journal of Biomedical and Pharmaceutical Sciences 3(22): 45-50.

Nagappan T. \& Vairappan, CS. (2014). Nutritional and bioactive properties of three edible species of green algae, genus Caulerpa (Caulerpaceae). Journal of Applied Phycology 26: 1019-1027.

Norra I., Aminah A., Suri R. \& Arif Zaidi, J. (2017). Effect of drying temperature on the content of fucoxanthin, phenolic and antioxidant activity of Malaysian brown seaweed, Sargassum sp. Journal of tropical agriculture and food science 45(1): 25-36.
Novoa AV., Andrade-wartha ERS., Linares AF., Si Lva Amo, Genovese Mi, González AEB., Vuorela P., Costa \& Mancini-Filho, J. (2011). Antioxidant activity and possible bioactive components in hydrophilic and lipophilic fractions from the seaweed Halimeda incrassata. Revista Brasileira de Farmacognosia 21: 53-57.

Ou B., Huang D., Hampsch-Woodill M., Flanagan J. \& Deemer, E. (2002). Analysis of antioxidant activities of common vegetables employing oxygen radical absorbance capacity (ORAC) and ferric reducing antioxidant power (FRAP) assays: A comparative study. Journal of Agricultural and Food Chemistry 50: 3122-3128.

Pattama R. \& Anong Chirapart (2002). Nutritional Evolution of Tropical Green Seaweed Caulerpa lentillifera and Ulva reticulata. Kasetsart Journal - Natural Science 40: 75-83.

Phang SM. (2006). Seaweed resources in Malaysia: Current status and future prospects. Aquatic Ecosystem Health and Management 9(2): 185-202.

Phang SM., Lim PE., Ooi JLS., Yeong HY., Ng W. \& Kupper, FC. (2008). Marine algae of Perak island, Jarak island and the Sembilan group of islands in the Straits of Malacca. Malaysia Journal of Science 27: 47-60

Phang SM., Wong CL., Lim PE., Yeong HY. \& Chan, CX. (2005). Seaweed diversity of Langkawi island with an emphasis on northern eastern region, Malaysia Journal of Science 24: 77-94.

Rajauria G., Jaiswal AK., Abu-Ghannam N. \& Gupta, S. (2012). Antimicrobial, antioxidant and free radical-scavenging 
capacity of brown seaweed Himanthalia elongata from western coast of Ireland. Journal of Food Biochemistry 37(3): 322-335.

Ramaiya SD., Bujang JB., Zakaria MH. \& Saupi, N. (2019). Nutritional, mineral and organic acid composition of passion fruit (Passiflora species). Food Research 3: 231-240.

Ramaiya SD., Bujang JS., Zakaria MH., King WS. \& Shaffiq, SMA. (2013). Sugars, ascorbic acid, total phenolic content and total antioxidant activity in passion fruit (Passiflora) cultivars. Journal of the Science of Food and Agriculture 93(5): 1198-1205.

Ramesh KS., Ramakritinan CM. \& Yokeshbabu, Y. (2012). Proximate composition of some selected seaweeds from Palk bay and Gulf of Mannar, Tamil Nadu, India. Asian Journal of Biomedical and Pharmaceutical Sciences 3(16): 1-5.

Rasyid A. (2017). Evaluation of Nutritional Composition of the Dried Seaweed Ulva lactuca from Pameungpeuk Waters, Indonesia. Tropical Life Sciences Research 28(2): 119-125.

Ruperez P. (2002). Mineral content of edible marine seaweeds. Food Chemistry 79: 23-26.

Sarini AW., Nor'Aishah H. \& Mohd Zaini, N. (2014). Determination of antioxidant activity for seven types of macroalgae. International Conference on Food Engineering and Biotechnoloy. IPCBEE vol. 65 .

Selvaraj K., Murugalakshmikumari R. \& Ramasubramanian, V. (2010). Bioremoval of nickel using seaweed as bioadsorbant. Journal of Basic and Applied Biology 4(3): 207-212.
Singleton VL. \& Rossi, JA. (1965). Colorimetry of total phenolics with phosphomolybdic phosphotungstic acid reagents. American Journal of Ecology and Viticulture 16: 144-158.

Thilahgavani N. \& Charles, SV. (2014). Nutritional and bioactive properties of three edible species of green algae, genus Caulerpa (Caulerpaceae). Journal of Applied Phycology 26: 1019-1027.

Thomas NV. \& Kim, SK. (2011). Potential pharmacological applications of polyphenolic derivates from marine brown algae. Environmental Toxicology and Pharmacology 32: 325-335.

USDA (2001). Agricultural research service. Nutrient Database for Standard Reference, Release 14.

Venugopal V. (2011). Polysaccharides from Seaweed and Microalgae Marine Polysaccharides Food Applications. CRC Press, USA.

Vinayak RC., Sudha SA. \& Chatterji, A. (2011). Bioscreening of a few green seaweeds from India for their cytotoxic and antioxidant potential. Journal of the Science of Food and Agriculture 91: 2471-2476.

Wardlaw GM. (2003) Contemporary nutrition: Issues and insights. McGraw-Hill.

Wijesingher WAJP. \& Jeon, YJ. (2012) Enzyme-assistant extraction (EAE) of bioactive components: a useful approach for recovery of industrially important metabolites from seaweeds: a review. Fitoterapia 83: 6-12.

Yap WF., Vangene T., Tan SH., Yoon-Yen Y. \& Jactty, C. (2019). Decoding antioxidant and antibacterial potentials of Malaysian green seaweeds: Caulerpa racemosa and Caulerpa lentillifera. Antibiotics 8: 152. 
Yow YY., Lim PE. \& Phang, SM. (2011) Genetic diversity of Gracilaria changii (Gracilariacea, Rhodophyta) from West Coast, Peninsular Malaysia based on mitochondrial cox1 gene analysis. Journal of Applied Phycology 23: 219226.

Zawawi MH., Idris MH., Kamal AHM. \& King, WS. (2015). Taxonomic assessment of seaweed community from the coastal areas of Bintulu, Sarawak, Malaysia. Songklanakarin Journal of
Science and Technology 37(2): 147153.

Zemke-White WL. \& Ohno, M. (1999) World seaweed utilization: An end-of-century summary. Journal of Applied Phycology 11: 369-376.

Zhou K. \& Yu, L. (2004). Effect of extraction solvent on wheat bran antioxidant activity estimation. LebensmittelWissenschaft und -Technologie 37: 717721. 